\title{
Pre-service Teachers Identify Connections between Teaching-learning and Literacy Strategies
}

\author{
Kimy Liu ${ }^{1}$, Quintin Robinson ${ }^{2}$, Jenelle Braun-Monegan ${ }^{3}$ \\ ${ }^{1}$ College of Education, California State University Stanislaus, California, United States. \\ ${ }^{2}$ Educational and Policy Studies, Southern Connecticut State University, Connecticut, United States. \\ ${ }^{3}$ School of Learning and Teaching, Pacific University, Oregon, United States. \\ Correspondence: Kimy Liu, College of Education, Kinesiology and Social Work, California State University Stanislaus, \\ 1 University Circle, Turlock, CA 95382, United States.
}

Received: April 11, 2016 Accepted: April 29, $2016 \quad$ Online Published: May 31, 2016

doi:10.11114/jets.v4i8.1538 URL: http://dx.doi.org/10.11114/jets.v4i8.1538

\begin{abstract}
This study explores the transformation of pre-service teachers in their attainment of effective teaching skills. Pre-service teachers learn about the learning-to-read process and implementations of component skills of teaching reading within the practicum. More importantly, pre-service teachers achieve a meaningful understanding of the declarative, procedural and strategic knowledge of working with struggling readers as well as the merits, utilities and appropriate applications of important literacy skills. Through reflecting, rehearsing, and revising teaching/learning practices, pre-service teachers are able to augment scripted Direct Instruction curriculum to improve student reading performance, and further generate meaningful learning gains that promote sustainability for themselves and their students.
\end{abstract}

Keywords: pre-service teachers, practicum, effective teaching skills, struggling readers, reading performance, revising teaching/learning practices

\section{Introduction}

\subsection{Teacher Preparation}

Workshops where teachers become passive participants is a commonly used Professional Development (PD) model for special education teachers; however, this approach results in limited impact on future instruction and the way teachers conduct classes (Dingle at al. 2011; Garet et al., 2008), partly because participants are inattentive passive learners who contribute little or nothing to the learning process. Our recommended practicum model is a learner-centered, "tell-show-try-apply" professional development model that engages participants throughout the learning process (Browder et al., 2012; Desimone, 2009; McLeskey, 2011). This model is grounded in four primary assertions of the teaching-learning process:

\subsection{Students}

Students do not care about how much you know, until they know how much you care. Responsive teaching should work in conjunction with domain expertise and give more weight in specific praises and immediate feedback that pre-service teachers can share with students (Brownell et al., 2009). Our model teaches practicum teachers to show they care by practicing "responsive teaching," which entails observing students closely and adjusting teaching pace based on students' responses.

Tedious repetitions in recalling details does not yield meaningful benefits in later retention efforts (Brown, Roediger \& McDaniel, 2014); therefore, it is imperative that teachers monitor and maintain student attention throughout the learning process. We provided differential reinforcements on desirable behaviors (such as reading words correctly with appropriate speed and expression), by acknowledging and rewarding students when they perform specific desirable behaviors.

\subsection{Special Education Students}

Special education students need explicit instruction and sufficient practice to retain foundational skills. For instance, reading with comprehension can be a challenge when it involves texts with unknown words or unfamiliar topics 
(Carnine, Silbert, Kame'emnui \& Tarver, 2010). To help students improve vocabulary knowledge and reading comprehension, pre-service teachers are prompted to supplement the DI scripts and provide learners "student-friendly explanations" to unknown words and model "think-aloud" on how to locate evidence to support their answers to comprehension questions. The gradual release of responsibilities makes the tasks challenging but feasible. This practice of focusing on vocabulary, comprehension, reasoning and elaboration is aligned with research supporting students with special needs to meet reading and language arts standards set in the Common Core Standards (Haager \& Vaughn, 2013 $\mathrm{a}, \mathrm{b})$.

Some pre-service teachers initially demonstrated poor teaching practices and failed to effectively engage students in the learning process. Those "light-bulb" moments that occurred through their trials and tribulations should be acknowledged, accepted, processed, and properly released and archived. These reflections can be at a content level or at a personal level. Efforts in which a pre-service teacher exerted reflective practice can make learning deeper and long lasting for students and the teacher.

\subsection{The Reading Process}

Many school districts have adopted Direct Instruction (DI) scripted lessons for remediation because of its effectiveness and its appearance of simplicity in training interventionists of DI. When administrators and pre-service teachers underestimate the complexity of teaching scripted DI reading lessons as remediation for students with special needs, they are less likely to exert the necessary efforts needed to fully understand implementation of the curriculum, learning needs of targeted students and the dual roles in the process for learning/teaching of a new program. With the absence of these needed efforts, student learning gains can become less apparent and ineffective.

Learning to read can be one of the most complex skills for students to acquire; remediating struggling readers can also be a difficult and complex process for teachers to master. The purpose of this study is to gain a better understanding of procedures and outcomes of the "learning-to-teach" behaviors of Pre-Service Teachers in the specific context of delivering scripted reading lessons and essential literacy strategies to students who struggle with reading. While most of the special education research focuses on efficacy of interventions, the content of effective professional development for pre-service special education teachers falls significantly behind the demand for teaching all students with rigor and transparency (Lang \& Fox, 2004; Leko \& Borwnell, 2009; McLeskey \& Ross, 2004; Sindelar et al., 2010).

\section{Method}

This study explored pre-service teachers' acquisition of teaching skills, in the context of providing struggling readers intervention with basic literacy skills. We assessed pre-service teachers' components skills in teaching DI scripted reading lessons during the pre-teaching training. During the practicum, we conducted four focused observations and subsequent debriefing for the pre-service teachers to reflect and receive feedback on their enactment of the scripted reading lessons. Tables 1 and 2 show the comprehensive assessment plan for the proposed practicum model, which includes the focus on different facets of acquiring essential skills for teaching struggling readers. The brief description of participants, pre-teaching training and practicum are provided in the next section.

Table 1. Pre-Teaching assessment

\begin{tabular}{lll}
\hline \multicolumn{1}{c}{ Name of Assessment } & \multicolumn{1}{c}{ Focus of Assessment } & \multicolumn{1}{c}{ Type of Assessment } \\
\hline 1. Reading Checkouts (1 min.) & $\begin{array}{l}\text { Competency in reading unfamiliar } \\
\text { texts in verbatim with appropriate } \\
\text { speed and expression }\end{array}$ & $\begin{array}{l}\text { Performance Assessment; } \\
\text { Standardized Test } \\
\text { Administration }\end{array}$ \\
\hline 2. Sound Checkouts (1 min.) & $\begin{array}{l}\text { Competency in verbally identifying } \\
\text { commonly used sounds or sound } \\
\text { combinations }\end{array}$ & $\begin{array}{l}\text { Performance Assessment; } \\
\text { Standardized Test } \\
\text { Administration }\end{array}$ \\
\hline 3. Quiz on DI Principles (30 min.) & $\begin{array}{l}\text { Foundational understanding of the } \\
\text { primers of teaching DI scripted } \\
\text { reading lessons. }\end{array}$ & Curriculum Based Assessment \\
& $\begin{array}{l}\text { Mock Teaching of a designated DI } \\
\text { lesson. }\end{array}$ & $\begin{array}{l}\text { Performance Assessment; } \\
\text { Checklist used }\end{array}$ \\
\hline 4. Lesson Checkouts (10 min.) & $\begin{array}{l}\text { Foundational knowledge on the test } \\
\text { administration and scoring of a } \\
\text { standardized reading assessment }\end{array}$ & Curriculum Based Assessment \\
\hline 5. Quiz on WRMT Test & & \\
Administration Procedure & & \\
\hline
\end{tabular}


Table 2. Teaching assessment via the coaching model

\begin{tabular}{|c|c|c|}
\hline $\begin{array}{l}\text { 6. Administration of WRMT as the } \\
\text { Pre and post tests }\end{array}$ & $\begin{array}{l}\text { Competency in administering and } \\
\text { scoring a standardized reading } \\
\text { assessment }\end{array}$ & Performance Assessment \\
\hline 7. Four Direct Observations & $\begin{array}{l}\text { Competency in teaching scripted DI } \\
\text { lessons and meeting the learning } \\
\text { needs of targeted students }\end{array}$ & Performance Assessment \\
\hline $\begin{array}{l}\text { 8. Teacher's Journals; Debriefing at } \\
\text { the Reflective Seminars }\end{array}$ & $\begin{array}{l}\text { Competency on conducting reflective } \\
\text { practice of responsive teaching }\end{array}$ & Peer and Self Evaluation \\
\hline $\begin{array}{l}\text { 9. Three Writing Assignments: Self } \\
\text { Evaluation on } \\
\text { DI teaching; Group Information and } \\
\text { Letter to Teachers }\end{array}$ & $\begin{array}{l}\text { Competency on conducting reflective } \\
\text { practice of responsive teaching and } \\
\text { communication one's teaching to } \\
\text { supervisor, peers and "consumers". }\end{array}$ & Peer and Self Evaluation \\
\hline
\end{tabular}

\subsection{Participation}

Up to sixteen pre-service teachers and sixty elementary and middle school students were recruited to participate in this study each semester. Participants invited to take part in the study were enrolled in the practicum. Prior to sending these practicum students to the designated school sites, all practicum teachers received three-weeks of intensive training based on Direct Instruction.

Three special education teachers of the participating school district referred students with mild disabilities and at-risk students to participate in the study. Parental consent and student assent were sought before including students in the study. Teacher A taught at a self-contained class for students with intellectual disabilities at a middle school. She created a rotation of learning stations for students to receive small group instruction; one of the learning stations was staffed with the practicum students. Teachers B and C were resource room teachers at the elementary level. They created a small homogeneous groups (i.e., students with similar reading levels and skills deficits), at their respective designated school sites, based on the students' prior education data, including but not limited to students' IEPs or pre-referral requests. The practicum students were responsible for tutoring the targeted students.

\subsection{Phase 1:Pre-teaching Training}

To remediate struggling readers, pre-service teachers were required to demonstrate competency on the critical components skills of teaching early literacy skills, show understanding of teaching students with special needs, and enact the research-based reading curriculum with fidelity. Teacher knowledge and teacher practice can influence student-learning outcomes (McCutchen et al., 2002).

\subsection{Phase 2: Practicum}

At the designated school sites, the first author (who also served as the practicum instructor and the university supervisor) created instructional teams to ensure that all practicum teachers taught 2 hours each week and all participating students received interventions four days a week. The length of interventions varied from site to site, but they were determined by the consensus of the teachers and the first author. Some school sites chose to have each student receive 30 minutes of intervention each day; while others chose to have each student receive 60 minutes of intervention per day. Each pre-service teacher was required to maintain communication and collaborate with team members, which including texting when the next lesson started and providing teaching recommendations.

The classroom expectations, teaching routines and teaching wordings remained consistent. During the practicum phase the pre-service teachers were required to reflect on their teaching. It was observed that: professional practice required participants to acknowledge and apply various innovations, which involves revising or expanding existing knowledge. According to Yoon et al. (2007), professional development with more than 14 hours showed significant impact on student achievement; ones with less than 14 hours showed no statistically significant effect on student achievement. Our pre-service teachers received 24 hours of pre-teaching training and 24 hours of field practice ( 2 hours per week for 12 weeks).

\subsection{Data Sources, Evidences, Objectives, Materials}

Evidence of the development of teaching skills of the pre-service teachers came from following data sources:

1. The pre-teaching assessment data that focused on the pre-service teachers' foundational knowledge of teaching and assessing struggling readers. 
2. Direct observation on pre-service teachers' enactment of scripted reading lessons.

3. Teaching Journals

4. Self-evaluation at the midpoint of their practicum.

5. Pre-service teachers completed a form that described the dynamics of their instructional groups and the selected intervention curriculum.

6. Summative reports written for the mentor teacher that described the learning outcomes of the interventions.

7. Debriefing from the reflective seminars.

8. The Woodcock Reading Mastery Test (WRMT) pre- and post-test data to quantify the learning gains as a result of the interventions.

9. The good-bye list that served as supplementary evidence for teaching effectiveness.

\section{Results}

In the fall 2013 WRMT data revealed that, on average, middle students gained 3.6 months of learning after receiving 10 weeks of interventions. In the spring 2014 data revealed that, middle students gained 7 months of learning after receiving 10 weeks of interventions. Elementary students participated in one session and middle school students participated in both intervention sessions.

All participating students could recite the rules and followed the rules throughout the lessons with minimal prompts and received frequent praises from pre-service teachers. Students knew the routines by heart and they appeared enjoying the routines. If a routine was interrupted, the student would remind the pre-service teacher of the routine. The same observations were reflected in the pre-service teachers' journals and notes from the debriefing sessions.

\subsection{Pre-service Teachers}

Pre-service teachers noted the following in their reflections:

1. Teaching at a brisk pace is more effective than teaching at a sluggish pace; students are more engaging when learning at a brisk pace.

2. Space practice paired with think time is more effective than massed practice with mindless repetition.

3. When dealing with student errors teachers should be quick to point out the error and follow up with immediate and specific error correction procedures.

4. The teacher should focus of teaching what makes sense in order to achieve student success.

5. Specific praise is instrumental towards building more disciplined and confident learners.

Effective learning strategies are simple and sometimes counterintuitive. The preconceived notions that pre-service teachers might have can either hinder or enhance their acquisition of teaching skills; however, upon the analysis of the pre-service teachers' journals and debriefing sessions we learned that:

1. Pre-service teachers appreciate the pre-teaching assessments.

2. We can use the actual teaching as the exercise to help students generate or activate prior knowledge.

3. Pre-service teachers are making connections between the course work and practicum experiences.

4. Pre-service teachers appreciate the uses of analogies and examples that connect to their everyday knowledge.

5. Pre-service teachers often struggled with the application of strategic knowledge, especially in the context of diagnosing the sources of learning errors.

6. Pre-service teachers need to make "judgment calls" and learn from those decisions.

7. Pre-service teachers appreciate time they have to rehearse, reflect, and revise their teaching practices.

\subsection{Significance of the Study}

There are estimated 40 to 50 percent of new teachers leave the profession within the first 5 years. Lack of support has been cited as a leading cause for teacher attrition (Ingersoll, 2003; Perda, 2013). Bridging the research-to-practice gap in the practicum can be the first step to remedy this situation (McLeskey \& Billingsley, 2008). Disseminating effective pedagogy is a goal of teacher preparation programs and faculty must take andragogy into consideration while designing learning expereinces. By helping pre-service teachers experience "beneficial struggles" in authentic learning, the faculty can better prepare teachers to be life-long learners and conduct reading interventions with competence and compassion. 


\section{Discussion}

According to Knowles, Holton, and Swanson (2014), how adults learn can be ostensibly different from the pedagogical model. The first task of facilitating adult learning is to secure the buy-in from the learner. The drive to know can become potent, if learners understand the urgency and significance of the knowledge. The student teachers in this study understood the importance of the practicum experience to enhance their learning. The second task of facilitating adult learning is to help learners to arrive at the self-concept of confident and competent learners, so that they are more likely to take ownership of their own learning. The third task of facilitating adult learning is to help learners maximize their prior experience. Instead of using "one-size-fits-all" instruction, the university faculty utilizes the coaching model and gives students individualized feedback on what they did right during the practicum and what are their areas in need of improvement. While helping adult learners to maximize knowledge, skills and experience they bring to enhance their learning, the university faculty also needed to be aware of the mental blocks, values, beliefs, and biases that adult learners have that could inadvertently undermine their learning. The university advisers must use an array of strategies to help adult learners to open their minds to new approaches and examine the efficacy of their practice. By validating the attributes, knowledge and skills the adult learners bring to the practicum and by providing needed coaching to remediate the negative effects of biases and skill deficits, the university faculty could help practicum students become more ready to learn and fully benefit from this field experience.

Furthermore, by making the task a slightly above the learners' current skills can help learners experience "desirable struggles", during which the skills and knowledge will be better learned and better retained (Bjork \& Bjork, 1992). The learning experience occurred during the practicum can be used to illustrate how some difficulties could elicit more willful efforts from learners, and how reflective practices were emerging during the think-time. These occurred between spacing of practice, interleaving, and mixing up practice. The seemingly inconvenience of reflecting during acquisition of the skills, instead of interrupting learning, actually make learning stronger, more enduring and more precise. By helping learners understand the rationale behind the scripts and signals, the practicum students learn to bridge the gap between theory and best practice. By helping pre-service teachers experience "desirable struggles" in authentic learning, the faculty can better prepare preservice teachers to be life-long learners and conduct reading interventions with compassion and competence.

\section{References}

Bjork, R. A., \& Bjork, E. L. (1992). A new theory of disuse and an old theory of stimulus fluctuation. In A. Healy, S. Kosslyn \& R. Shiffin (Eds.), From learning processes to cognitive processes: Essays in honor of William K. Estes, 2, 35-67. Hillsdale, NJ: Earlbaum.

Browder, D. M., Jimenez, B. A., Mims, P. J., Knight, V. F., Spooner, F., Lee, A., \& Flowers, C. (2012). The effect of a "tell-show-try-apply" professional development package on teachers of students with severe developmental disabilities. Teacher Education and Special Education, 35(2), 212-227. http://dx.doi.org/10.1177/0888406411432650

Brown, P. C., Roediger, H. L., \& McDaniel, M. A. (2014). Make it stick: The science of successful learning. Boston: Belknap Press. http://dx.doi.org/10.4159/9780674419377

Brownell, M. T., Bishop, A. G., Gersten, R., Klinger, J. K., Penfield, R. D., Dimino, J., Haager, D., Menon, S., \& Sindelar, P. T. (2009). The role of domain expertise in beginning special education teacher quality. Exceptional Children, 75(4), 391-411. http://dx.doi.org/10.1177/001440290907500401

Carnine, D. W., Silbert, J., Kame'enui, E. J., \& Tarver, S. G. (2010). Direct instruction reading (5 ${ }^{\text {th }}$ edition.). Upper Saddle River, New Jersey: Pearson Education

Desimone, L. M. (2009). Improving impact studies of teachers' professional development: Toward better conceptualizations and measures. Educational Researcher, 38(3), 181-199. http://dx.doi.org/10.3102/0013189X08331140

Dingle, M. P., Brownell, M. T, Leko, M. M., Boardman, A. G., \& Haager, D. (2011). Developing effective special education reading teachers: The influence of professional development, context, and individual qualities. Learning Disability Quarterly, 34(1), 87-103. Retrieved from ERIC database. http://dx.doi.org/10.1177/073194871103400106

Garet, M. S., Crone, S., Eaton, M., Kurki, A., Ludwig, M., Jones, W., Uekawa, K., Falk, A., Bloom, H. S., Doolittle, F., Zhu, P., Sztenjnberg, L., \& Silverberg, M. (2008). The impact of two professional development interventions on early reading instruction and achievement. Washington, DC: National Center for Evaluation and Regional Assistance, Institute of Education Sciences, U.S. Department of Education. Retrieved from http://ies.ed.gov/ncee/ 
Haager, D., \& Vaughn, S. (2013a). Common core state standards and students with learning disabilities: Introduction to the special issue. Learning Disabilities Research and Practice, 28(1), 1-4. Retrieved from ERIC database. http://dx.doi.org/10.1111/ldrp.12005

Haager, D., \& Vaughn, S. (2013b). The common core state standards and reading: Interpretations and implications for elementary students with disabilities. Learning Disabilities Research and Practice, 28(1), 5-16. Retrieved from ERIC database. http://dx.doi.org/10.1111/ldrp.12000

Ingersoll, R. (2003). Is there really a teacher shortage? CPRE Research Report \# R-03-4. Philadelphia: Consortium for Policy Research in Education, University of Pennsylvania.

Knowles, M. S., Holton III, E. F., \& Swanson, R. A. (2014). The adult learner: The definitive classic in adult education and human resource development. $\left(8^{\text {th }}\right.$ ed.). New York: Routledge.

Lang, M., \& Fox, L. (2004). Breaking with tradition: Providing effective professional development for instructional personnel supporting students with severe disabilities. Teacher Education and Special Education, 27(2), 163-173. http://dx.doi.org/10.1177/088840640402700207

Leko, M. M., \& Brownell, M. T. (2009). Crafting quality professional development for special educators: What school leaders should know. Teaching Exceptional Children, 42(1), 64-70. Retrieved from ERIC database. http://dx.doi.org/10.1177/004005990904200106

McCutchen, D., Abbott, R. D., Green, L. B., Beretvas, B. N., Cox, S., Potter, N. S., Quiroga, T., \& Gray, A. L. (2002). Beginning literacy: Links among teacher knowledge, teacher practice, and student learning. Journal of Learning Disabilities, 35(1), 69-86. Retrieved from ERIC database. http://dx.doi.org/10.1177/002221940203500106

McLeskey, J. (2011). Supporting improved practice for special education teachers: The importance of learner-centered professional development. Journal of Special Education Leadership, 21(1), 26-35.

McLeskey, J., \& Billingsley, B. S. (2008). How does the quality and stability of the teaching force influence the research-to-practice gap? A perspective on the teacher shortage in special education. Remedial and Special Education, 29(5), 293-305. http://dx.doi.org/10.1177/0741932507312010

McLeskey, J., \& Ross, D. D. (2004). The politics of teacher education in the new millennium: Implications for special education teacher educators. Teacher Education and Special Education, 27(6), 342-349. http://dx.doi.org/10.1177/088840640402700402

Perda, D. (2013). Transitions into and out of teaching: A longitudinal analysis of early career teacher turnover (Unpublished doctoral dissertation). University of Pennsylvania, Philadelphia.

Sindelar, P. T., Brownell, M. T., \& Billingsley, B. (2010). Special education teacher education research: Current status and future directions. Teacher Education and Special Education, 33(1), 8-24. http://dx.doi.org/10.1177/0888406409358593

Yoon, K. S., Duncan, T., Wen-Yu Lee, S., Scarloss, B., \& Shapley, K. L. (2007). Reviewing the evidence of how teacher professional development affects student achievement. (Issues \& Answers Report, REL 2007-No. 033). Washington, DC: US Department of Education, Institute of Educational Sciences, National Center for Evaluation and Regional Assistance, Regional Educational Laboratory Southwest. Retrieved from http://ies.ed.gov/ncee/edlabs

This work is licensed under a Creative Commons Attribution 3.0 License. 